\title{
STUDY ON BUILDING SANITATION SITUATION IN URBAN CENTRE
}

\author{
Sheikh Anwarul Mahdi \\ Department of Civil Engineering \\ Ahsanullah University of Science and Technology, \\ Dhaka, Bangladesh. \\ Md. Mynul Karim \\ Department of Civil Engineering \\ Ahsanullah University of Science and Technology, \\ Dhaka, Bangladesh.
}

\begin{abstract}
Bangladesh is considered one of the world's most densely populated countries with 2,889 people per square mile. Dhaka, the capital, is one of Asia's fastest growing cities, with a population density of $1,21,720$ per square mile. A look at the water, sanitation and hygiene challenges faced by one the world's fastest growing megacities-Dhaka, Bangladesh, where thousands of people are affected by toxic chemicals, dust, air pollution, sound pollution which cause numerous diseases on human body. The unscientific disposal of solid waste which producing toxic and infectious material in Dhaka city causes infection. The buildings are being congested due to small road width between them and are interrupt the free wind flow and sunlight that introduced poor ventilation that has been linked to respiratory diseases such as asthma, and can also facilitate the spread of diseases. It has also been linked with allergies, pneumonia, fatigue, nausea, dry eyes, headaches and nasal congestion.
\end{abstract}

Based on the need for effective solutions of building sanitation situation, this research includes the theoretical background and explanation of several methods. There are many theories in the community, but the ones chosen to be looked closer at here is survey based analysis.

Survey based analysis is used to know the adverse effect of the building on human body. Manual and visual, questionnaire based survey was performed to attain the current situation of building sanitation and the health effect of the dwellers. A survey and in depth interview was conducted in fifty different households in various areas in Dhaka city. Anyone may get a clear concept about the buildings sanitation problems of some areas in Dhaka city by going through this. The building itself become a threat for the residents if it is not properly constructed or well maintained. The Living Building

\author{
Rashed Alam \\ Department of Civil Engineering \\ Ahsanullah University of Science and Technology, \\ Dhaka, Bangladesh. \\ Md. Zobair Alam \\ Department of Civil Engineering \\ Ahsanullah University of Science and Technology, \\ Dhaka, Bangladesh.
}

Challenge and other programs that include "red lists" of substances to avoid are based on the principle of hazard avoidance. The idea is attractive in its logic. Certain chemicals are dangerous; we should avoid using those chemicals. Inadequate building sanitation causes various diseases and that brings much more sufferings. The quality of indoor air is very poor due to insufficient ventilation system. The most warning problem is waste collection and management system. Apart this, the old buildings are suffered damp issues. To control this bad effect of building sanitation situation government should raise awareness about building sanitation system. The research is important because most of the dwellers have no idea about the building sanitation, as well as its affect. The reader may come to a point after reading this paper and understand what building sanitation is.

Keywords: Dhaka, Sanitation, Garbage, Health status, Building Problems, Pollution, Water.

\section{INTRODUCTION}

Building is generally built for the comfort of the residents but sometimes it may be cause for the discomfort. The general parameters should be under consideration while building the houses that is why the dwellers may not face any problem. From BNBC 2006, the standard definition of building is found. Any permanent or semi-permanent structure which is constructed or erected for human habitation or storage or any other purpose and includes the foundation plinth, walls, floors, roofs, chimneys , fixed platform, verandah, balcony, cornice, projections, extensions, annexes and any land or spaces enclosed by wall adjacent to it. The term building will also include sanitary, plumbing, HVAC, outdoor display structure, sings and all other building service installations, which are constructed or erected as an integral part of building. Sanitation generally refers to the provision of facilities and services for the safe 
disposal of human urine and faces. Inadequate sanitation is a major cause of disease worldwide and improving sanitation is known to have a significant beneficial impact on health both in households and across communities. The word 'sanitation' also refers to the maintenance of hygienic conditions, through services such as garbage collection and wastewater disposal. Sanitation is a hygienic disposal or recycling of waste. It also considered as a practice that allows protecting health only with the help of hygienic measures.

\section{OBJECTIVE OF THE STUDY}

The problems due to faulty sanitation practices should be fixed as early as possible because these may bring various diseases as well as death. In this study, the whole matter is discussed very easily to make awareness among the people. The objectives of the study is-

- To make know the people about the building sanitation.

- To identify the adverse effects due to faulty sanitations.

\section{METHODOLOGY}

A survey was performed in several areas of Dhaka city where the sanitation systems were unsatisfactory. The areas are- Mirpur, Tejgaon, Sabujbag (Mugda), Dakhshinkhan (Ashkona), Magbazar. Here both primary and secondary data's were collected. Primarily data was collected by visual and manual survey. On the other hand secondary data was collected from different codes of building regulation.

\section{A. Primary data-}

The data were collected in and around different houses of the study area along with other sources. Observation was done by transect walk in the study and necessary notes were taken in the notebook. Photographs were taken during the observation. 10 residential buildings in 5 areas were selected for case studies.

\section{Manual survey-}

Mainly the frontage, minimum side and rear space of the plot, roadway width, floor area of the house, number of occupants, occupants density, percentage of window opening etc. various data were surveyed by using steel tape gauge and so on.

\section{Visual survey-}

Visual survey is conducted to know deep about the ventilation system, air conditioner type, waste collection system, water availability, plumbing problems and damp presence in the building.

\section{In depth interview-}

A set of questions are asked to the residents about the condition of dust problems, chemical contaminants from indoor and outdoor sources, gas leakage, noise hazards, duration of day lighting, heat, quality of water and toilet environment etc. and the effect of this on human body.

\section{Sample Questionnaire-}

An elaborate informative questionnaire was made having all the needful information of the building and the common problem of a building. Though there are various questions in the form but all the observations were not conducted. We gather the answers according to this questionnaire. The copy of the questionnaire is stated in 'Appendix-I'.

\section{$B$. Secondary data-}

Secondary data is the data collected by someone other than the user. Common sources of secondary data for social science include censuses, organizational records and data collected through qualitative methodologies or qualitative research.

\section{DATA ANALYSIS}

\section{$A$. Surroundings of the building-}

Building surroundings means its frontage and minimum rear \& side open space. A building's immediate surroundings change its effective weather patterns, as nearby buildings or trees can block sunlight and change wind patterns.

\section{Frontage-}

Frontage is the length of the side of a plot facing the street. There may be more than one frontage depending on the location of a plot with respect to the street. Irrespective of the height of building frontages shall be constructed at a distances of at least $4.5 \mathrm{~m}$ from the midpoint of the public or private street or road width or at a distance of at least $1.5 \mathrm{~m}$ plot abutting streets or roads edges whichever is greater.

Table 1: Frontage of the buildings

\begin{tabular}{|c|c|c|c|}
\hline Study Area & $\begin{array}{c}\text { Plot size } \\
\left(\mathrm{ft}^{2}\right)\end{array}$ & $\begin{array}{c}\text { Average } \\
\text { width of } \\
\text { front road } \\
(\mathrm{ft})\end{array}$ & $\begin{array}{c}\text { Minimum } \\
\text { frontage }(\mathrm{ft}) \\
\text { by BNBC }\end{array}$ \\
\hline Mirpur & 1080 & 14 & 23 \\
\hline Tejgaon & 1066 & 10 & 23 \\
\hline $\begin{array}{c}\text { Sabujbag } \\
\text { (Mugda) }\end{array}$ & 1210 & 13 & 23 \\
\hline $\begin{array}{c}\text { Dakhshinkhan } \\
\text { (Ashkona) }\end{array}$ & 1140 & 13.5 & 23 \\
\hline Magbazar & 1111 & 13 & 23 \\
\hline
\end{tabular}


International Journal of Engineering Applied Sciences and Technology, 2020

Vol. 5, Issue 3, ISSN No. 2455-2143, Pages 66-74

Published Online July 2020 in IJEAST (http://www.ijeast.com)

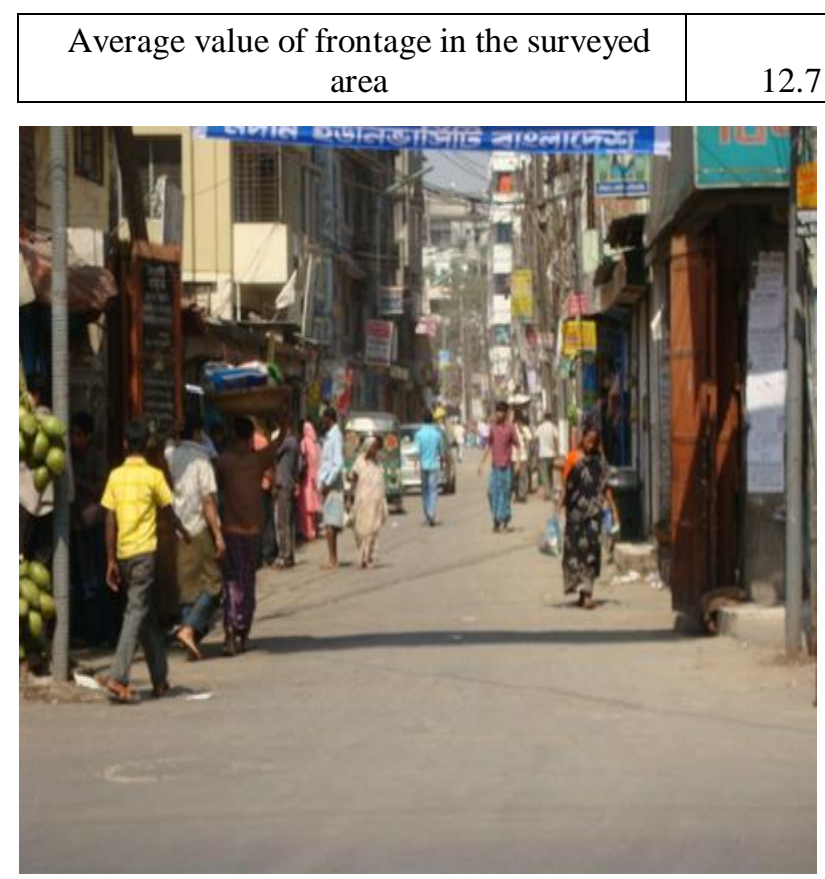

Fig. 1. Buildings constructed without minimum frontage in Mirpur

\section{Minimum Rear and Side Open Space Requirements of} a Plot-

Minimum open space requirements for the sides, rear and frontages of a plot shall be as per the provisions of this code or the authority having jurisdiction. At least $50 \%$ of the mandatory open space in a plot shall remain unpaved with or without vegetation to allow water penetration. The total open area in a plot on which a building of educational, institutional, health care occupancy is constructed shall not be less than $50 \%$ of the plot area.

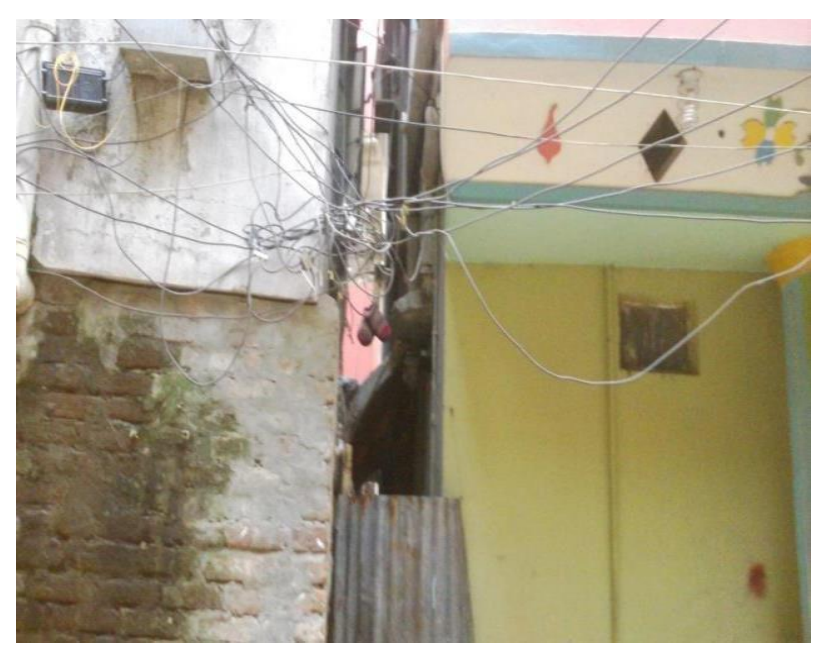

Fig. 2. Risky wire and No side spacing (Picture has taken from Farmgate)

\section{Rear and Side Open Space of the Buildings}

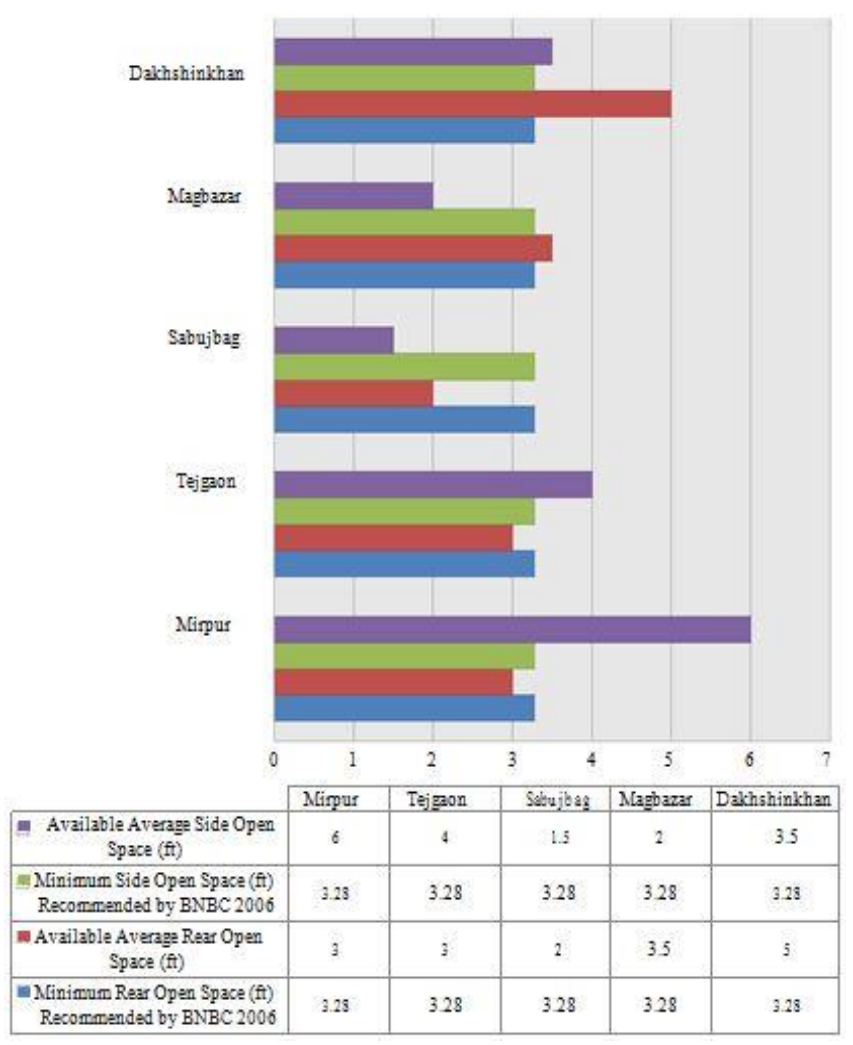

Fig. 3. Rear and Side Open Space of the Buildings

\section{$B$. Indoor air quality-}

\section{Chemical Contaminants from indoor sources-}

The toxic chemicals of most concern in diesel exhaust are the oxides of nitrogen (nitric oxide, nitrogen dioxide), sulfur dioxide, aldehydes, primarily formaldehyde, acetaldehyde, acrolein and various hydrocarbons particles. Carbon monoxide is also present. The higher average temperature of combustion of diesel engines generates more oxides of nitrogen than gasoline engines.

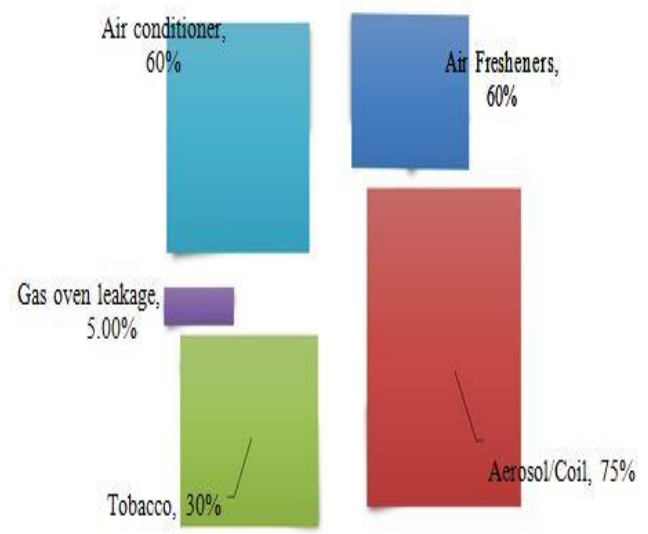




\section{International Journal of Engineering Applied Sciences and Technology, 2020 \\ Vol. 5, Issue 3, ISSN No. 2455-2143, Pages 66-74 \\ Published Online July 2020 in IJEAST (http://www.ijeast.com)}

Fig. 4. Percentage of Chemical Contaminants from indoor sources in Dhaka City.

The result of survey in some areas of Dhaka City like Mirpur, Farmgate, Sabujbag, Magbazar and Dakhshinkhan and found that the tendency of using Air freshener, Aerosol, Coil or consuming tobacco is very high and they do not know the detrimental effect of this on indoor air quality.

\section{Dust problem:}

Dust, with high concentrations of poisonous elements, is an integral part of this pollution. Environmental activists say dust pollution has already reached an alarming stage but there is hardly any initiative visible to address it.

High Dust Problem $\square$ Medium Dust Problem $\square$ Low Dust Problem

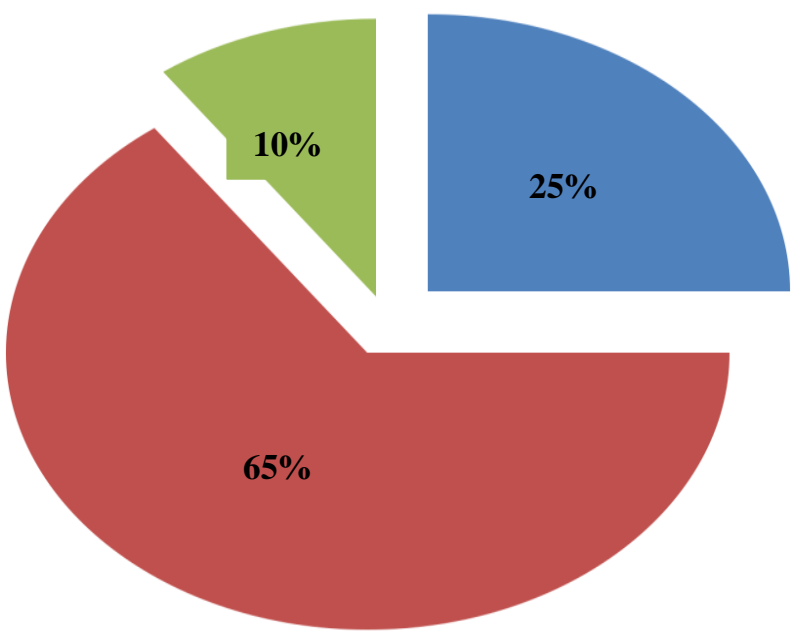

Fig. 5. Comparison of high, medium and low Dust problem in Dhaka city

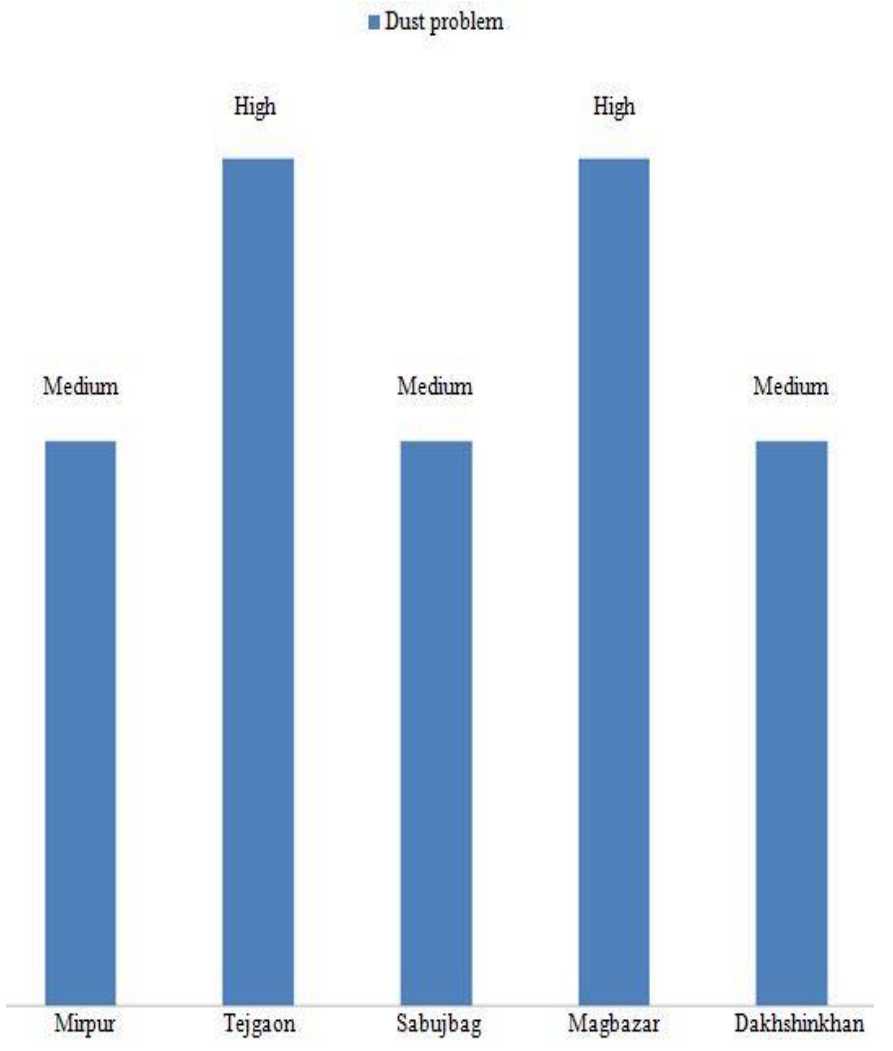

Fig. 6. Dust problems in Houses in Dhaka City

In the buildings of Mirpur, Sabujbag and Dakhshinkhan area we found the dust problem is medium. Because of less vehicle emission or construction work, the dust problem is medium. But in, Tejgaon and Magbazar area the problem is acute.

\section{Chemical contaminants from outdoor sources-}


International Journal of Engineering Applied Sciences and Technology, 2020

Vol. 5, Issue 3, ISSN No. 2455-2143, Pages 66-74

Published Online July 2020 in IJEAST (http://www.ijeast.com)

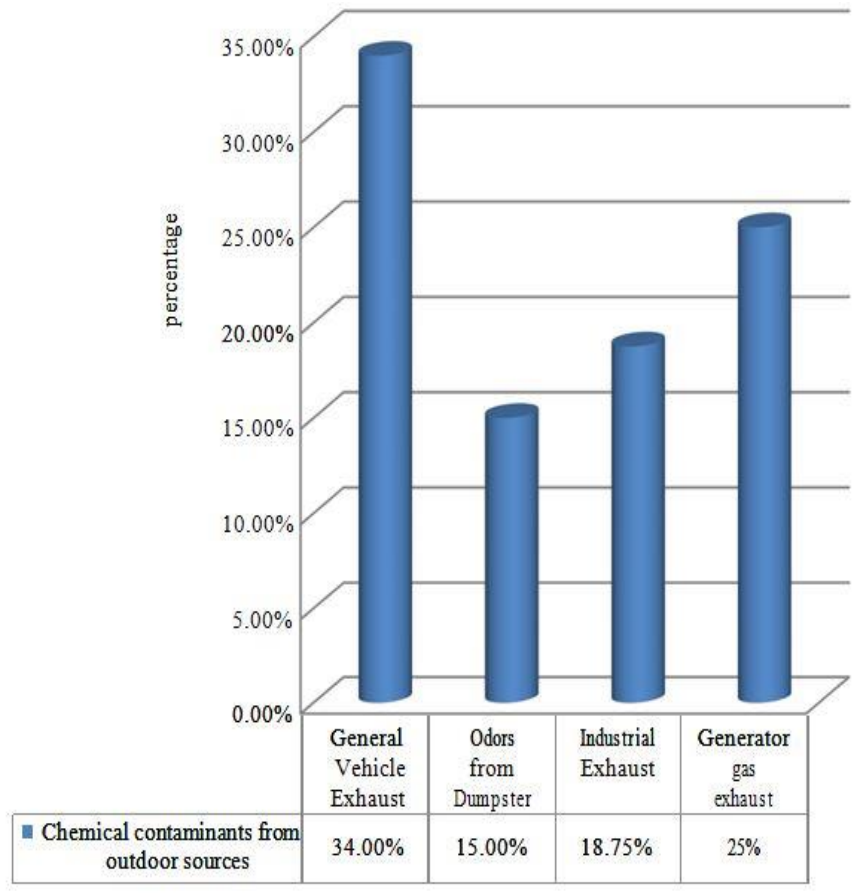

Fig. 7. The percentage of outdoor chemical contaminants

About $34 \%$ chemical contaminants is come from the vehicle exhaust and from dumpster. In Dhaka city, $18.75 \%$ contaminants from outdoor sources is industrial exhaust. Moreover, about $25 \%$ emission is from the generator which is usually kept in the ground floor of the building.

\section{$C$. Domestic waste collection system-}

As per traditional method of waste collections Rickshaw vans are modified to collect waste from each house and City Corporation has their own vehicles for collecting wastes.

For the survey various primary data and survey in our pre located areas and by questionnaires, we mark the waste collection systems. Usually house-to-house collection of garbage with the initiative and efforts of the community is done widely, while in some specific areas the households bring their refuse to the nearby communal bins/containers located on the street side. These collected wastes are deposited in the bins on some convenient spots of the streets. The household, commercial, institutional and medical wastes are deposited in the same waste collection bins located on the streets. Street sweeping is done manually and debris are loaded from the Curbside into the handcarts and delivered into the collection bins.

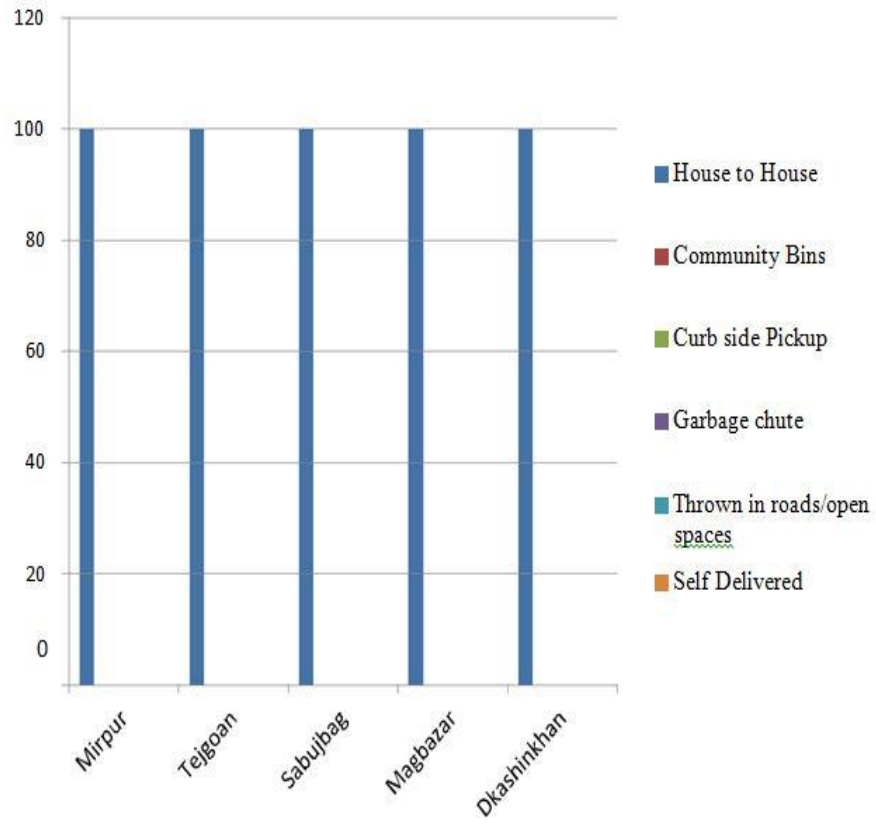

Fig. 8. A graphical comparison of Waste collection system based on Questionnaire

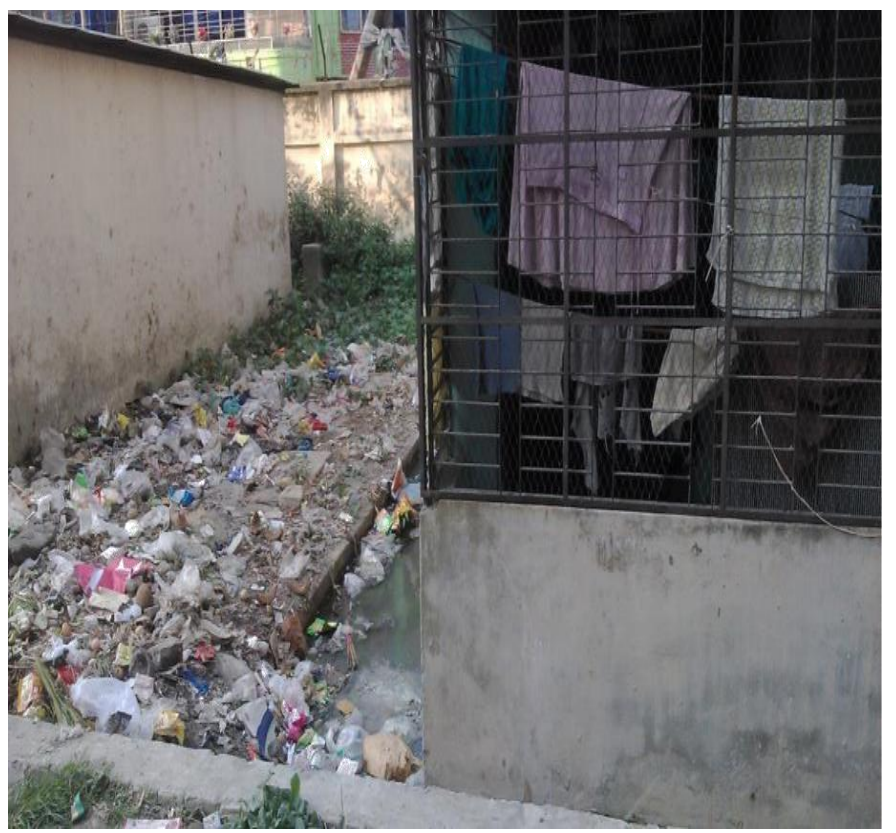

Fig. 9. Domestic wastes thrown away and drain clogging (Picture has taken from Sabujbag (Mugda))

\section{$D$. Water quality-}

In this table, results present the current phase of water quality in various areas of Dhaka City (Based on questionnaire): 
Table 2. Current phase of water quality in various areas of Dhaka City (Based on questionnaire)

\begin{tabular}{|c|c|}
\hline Study Area & Water quality \\
\hline Mirpur & $\begin{array}{c}\text { Presence of turbidity and } \\
\text { Presence of bacteria }\end{array}$ \\
\hline Tejgaon & Presence of bacteria \\
\hline Sabujbag & $\begin{array}{c}\text { Presence of bacteria and bad } \\
\text { taste }\end{array}$ \\
\hline Magbazar & Presence of bacteria \\
\hline Dakhshinkhan & Presence of bacteria \\
\hline
\end{tabular}

\section{$E$. Plumbing problems in Dhaka city-}

It is the major problem in most of the residential buildings in Dhaka City. It affects the building sanitation as well as the dwellers.

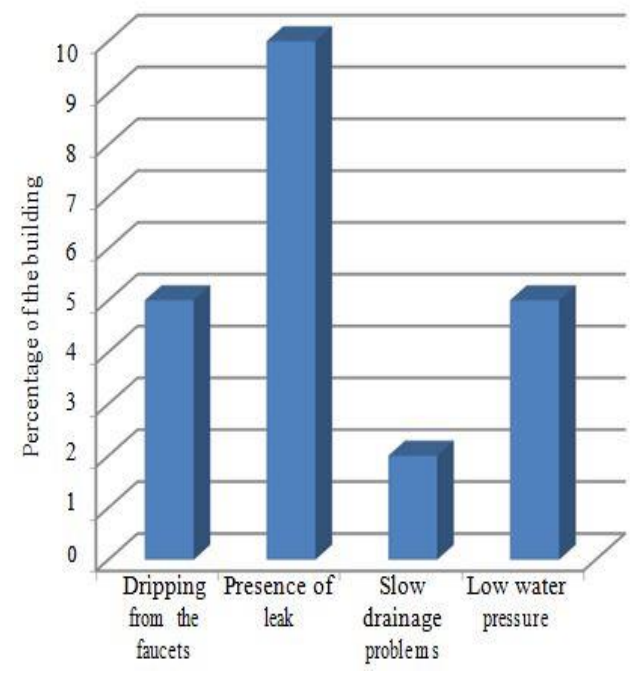

- Visible plumbing problems

Fig. 10. Visible plumbing problems in Dhaka City

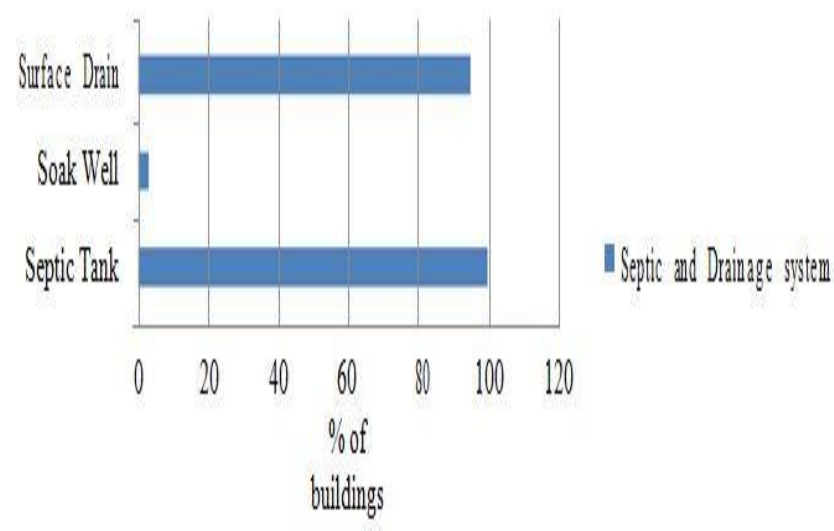

Fig. 11. Septic and Drainage system in Dhaka City

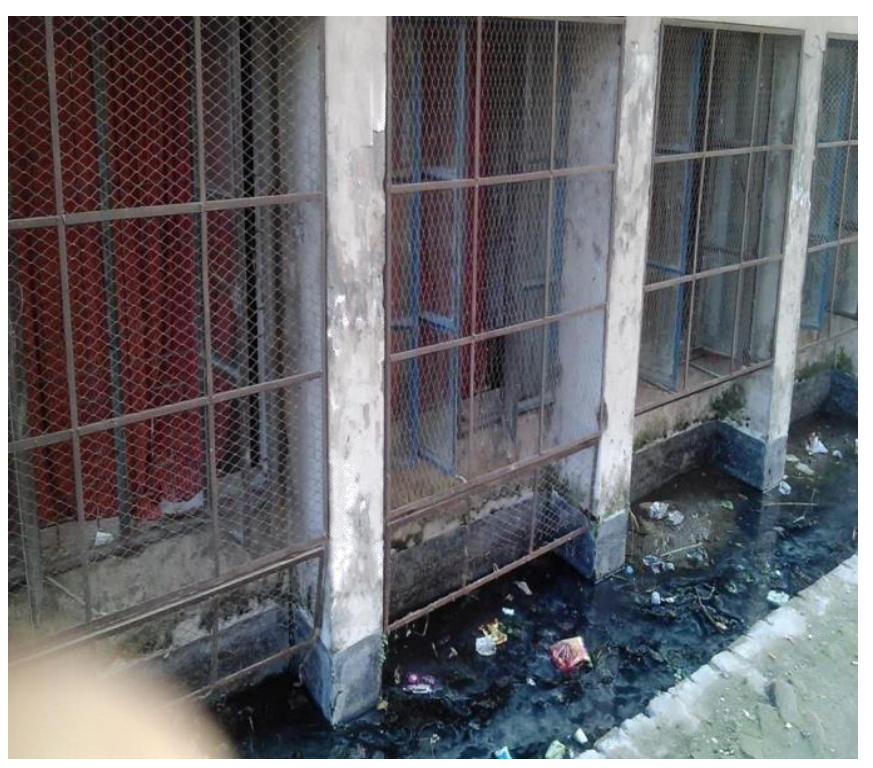

Fig. 12. Plumbing hazards in Mirpur

\section{$F$. Dampness problems in Dhaka city-}

From the Questionnaire, we can present the recent dampness problem in Dhaka City. In Mirpur, Tejgaon, Magbazar areas we found the problem is very. Ventilation system, window openings and all the parameter are good enough that's why the dampness in quite low. There are many newly constructed buildings and the number of old building is less. In Sabujbag, Dakhshinkhan we found some dampness problem. Most of the problem is rising damp, penetrating damp, damp from plumbing leaks etc. these indicate the faulty old constructed buildings, inadequate ventilation system, relative humidity etc. Here we represent the percentage of various dampness in various localities in Dhaka city.

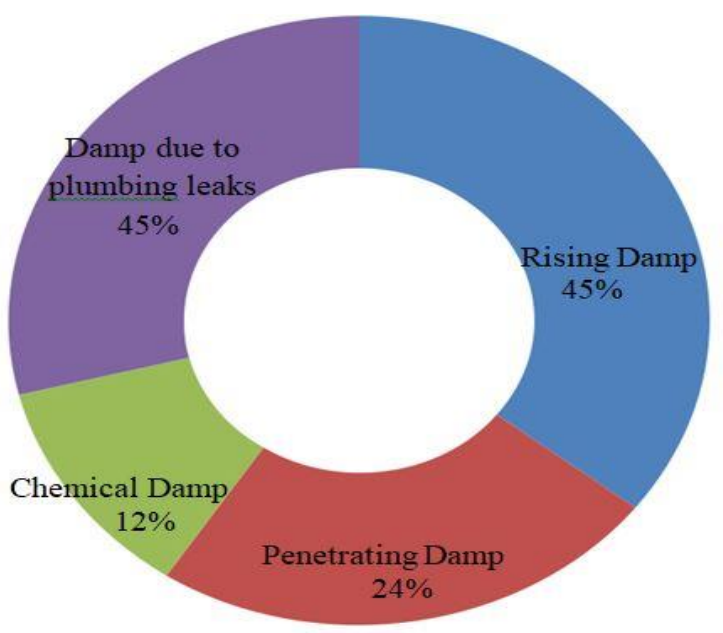

Fig. 13. Percentage of Dampness in Dhaka city 
International Journal of Engineering Applied Sciences and Technology, 2020

Vol. 5, Issue 3, ISSN No. 2455-2143, Pages 66-74

Published Online July 2020 in IJEAST (http://www.ijeast.com)

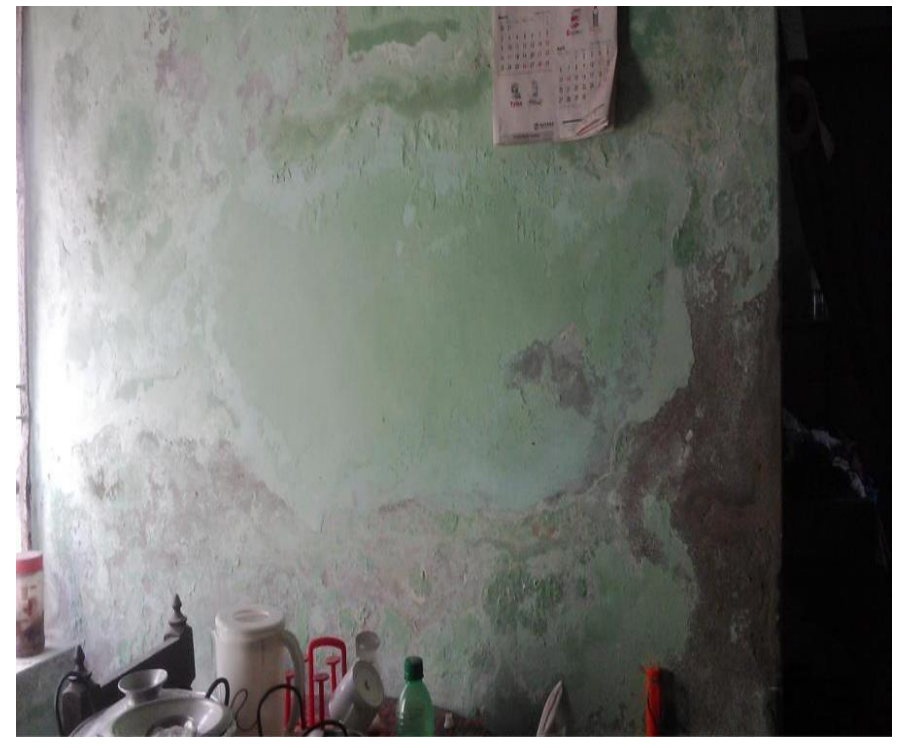

Fig. 14. A damp wall (Picture has taken from Sabujbag (Mugda))

\section{DISCUSSIONS}

The buildings are being congested due to small road width between them and are interrupt the free wind flow and sunlight. Maximum residential buildings have fewer frontages than required, which is in average $12.7 \mathrm{ft}$ only while it should have been $23 \mathrm{ft}$ according to BNBC. (Table 1 \& Fig. 1)

Side and rear open space varies place to place. Buildings in place like Mirpur, Tejgaon, and Magbazar have got more space than required but buildings in place like Sabujbag, Dakhshinkhan have got less space than required. Overall in Dhaka city the average percentage of side opening is $3.64 \mathrm{ft}$ and rear opening is $4.14 \mathrm{ft}$ while required space is $3.28 \mathrm{t}$. (Fig. 2 \& Fig. 3)

The toxic chemicals of most concern in diesel exhaust are the oxides of nitrogen (nitric oxide, nitrogen dioxide), sulfur dioxide, aldehydes, primarily formaldehyde, acetaldehyde and acrolein, and various hydrocarbons particles. Carbon monoxide is also present. The higher average temperature of combustion of diesel engines generates more oxides of nitrogen than gasoline engines. (Fig. 4, Fig. 7)

$10 \%$ of residential buildings have low dust problem in Dhaka city. Among rest areas $25 \%$ have high and another $65 \%$ have medium dust problem. (Fig. 5, Fig. 6)

Almost every residential building has got water problem. The quality of water is very poor as $2 \%$ buildings have bad test, $5 \%$ turbid and 3\% salinity problem \& $90 \%$ building have bacteria problem. (Table 2)
In Dhaka city $5 \%$ buildings have got dripping from the faucet problem, $10 \%$ leakage and slow drainage problem and $5 \%$ have got low water pressure problem. (Fig. 10, Fig. 11, Fig. 12)

Almost every building has dampness problem.12\% buildings have chemical damp problem, 24\% penetrating damp, $45 \%$ rising and $15 \%$ buildings have got damp due to plumbing leak problem. (Fig. 13, Fig. 14)

Poor ventilation can also create rust and affect any plumbing or pipe work that may run through the various rooms in the home. It may also cause venting straps to malfunction.

This is perhaps one of the most severe consequences of poor ventilation in a property. A lack of ventilation has been linked to respiratory diseases such as asthma, and can also facilitate the spread of diseases. It has also been linked with allergies, pneumonia, fatigue, nausea, dry eyes, headaches and nasal congestion. However, by installing a system that helps to distribute air evenly throughout a home, it is possible to avoid these unpleasant side-effects. As a room cools and warms with the day, frost can build up on the windows and in other areas of the home. The buildup of damp and humidity in a building can create an unpleasant and musty odor, which can spread to other areas of the home. This fragrance can be particularly not easy to get rid of, unless the air quality in the property is improved.

Among all the areas Magbazar, Tejgaon is found too much unhealthy. Mirpur, Dakhshinkhan, are also not healthy for living. But survey shows that Sabujbag (Mugda) is preferable and suitable for living.

\section{RECOMMENDATIONS}

- The buildings are being congested due to small road width between them and are interrupt the free wind flow and sunlight. Reduction of front road width is also an illegal deed and proper steps should be taken. The house owner must be conscious about frontage.

- Rear and side opening should be spacious for ventilation and lighting purpose.

- Occupant density should be strictly controlled.

- Percentage of window opening should be $40 \%$ to control humidity, cooling and heating hours etc.

- Ventilation system must be outstanding because light, air etc. passes through this and many diseases caused by this.

- Indoor air is becoming an increasingly more concerning health hazard than outdoor air. Using ventilation to dilute contaminants, filtration, and Source control are the 


\section{International Journal of Engineering Applied Sciences and Technology, 2020 \\ Vol. 5, Issue 3, ISSN No. 2455-2143, Pages 66-74 \\ Published Online July 2020 in IJEAST (http://www.ijeast.com)}

primary methods for improving indoor air quality in most buildings and reducing Exposure to Biological Contaminants.

- Bed and couches should not place near a wall where the radiations are high. If there is enough land, then home planting trees between house and the cell tower will offer some protection. Trees help absorb radiation. Using radiation-blocking paint or wall-covering or other shielding devices. Windows are usually the most vulnerable spots in the home. So, there is a special window film that comes in a roll from Scotch tint - which minimize the exposure to EMF pollution.

- Garbage chute system should be introduced. While collecting wastes by house to house system, the odor spreads from lift to all the building.

- The damp maybe minimize by Getting rid of existing mould in the property, eliminating excess moisture, proper insulation, increase ventilation, heating the property. And. Protection of buildings against dampness may be taken by Membrane Damp Proofing, Integral Damp Proofing, Surface Treatment, Grunting and Cavity Wall Construction.

\section{REFERENCES}

[1] Bangladesh National Building Code, (2006).

[2] Bahauddin K.M. an Salah T., "Status of Particulate Matter and Its Impact on Roadside Population of Dhaka City, Bangladesh: A Review Study."

[3] M. Russell, M. Sherman and A. Rudd "Review of Residential Ventilation Technologies ."

[4] Walting P.K. and How J.L. (2001), "Ventilation For Acceptable Indoor Air Quality, ANSI/ASHRAE, Addendum N To ANSI/ASHRAE Standard 62."

[5] Dasgupta S., Huq M., Pandey K..D., Dr. Khaliquzzaman M., Wheeler R. D., Exposure to indoor air pollution in Bangladesh.

[6] Kumar S., Building Construction.

[7] Kanti P., Hayakawa S., Characteristics of Air Pollution Condition in Dhaka City- Effect of Automobiles and Factories on Environment.

[8] Muhammad M., Noise Pollution in Dhaka City.

[9] http://civildigital.com/domestic-sewage-treatmentseptic-tank-and-soak-pits/

[10] http://en.wikipedia.org/wiki/Natural_ventilation
[11] http://en.wikipedia.org/wiki/Sanitation

[12]http://noisepollution.weebly.com/sources-of-noisepollution.html

[13]https://www.stratford.gov.uk/community/bin-collectioncalendar.cfm

[14] http://www.dampproofing-london.co.uk/damp.htm

[15] http://www.cdc.gov/mold/dampness_facts.htm

[16]http://www.nhlbi.nih.gov/health/healthtopics/topics/vent/risks

[17] Website of Department of Environment, Bangladesh

[18] Website of World Health organization

\section{ACKNOWLEDGEMENT}

Firstly, we would like to express our gratitude towards Almighty Allah for enabling us to complete this project work successfully.

We would like to express our indebtedness, sincere appreciation and deepest gratitude to our thesis supervisor Rumana Afrin, Assistant Professor, Department of Civil Engineering, Ahsanullah University of Science and Technology for her impeccable supervision, valuable instructions, sincere advice and encouragement towards us. Without her contribution, this research work could not have been completed.

Finally, we are grateful to our family members and friends and to each other in the group for a humble cooperation in completing this report in time. 
International Journal of Engineering Applied Sciences and Technology, 2020

Vol. 5, Issue 3, ISSN No. 2455-2143, Pages 66-74

Published Online July 2020 in IJEAST (http://www.ijeast.com)

\section{APPENDIX I}

Questionnaire

Date

STUDY ON BUILDING SANITATION SITUATION IN DHAKA CITY

1. Address of the Building

\begin{tabular}{|c|c|c|c|}
\hline \multicolumn{4}{|l|}{ 2. Information of the Building: } \\
\hline 2.1 Occupancy Type & $\checkmark$ Residential & $\square$ Office & $\square$ Commercial \\
\hline \multirow{4}{*}{$\begin{array}{l}2.2 \text { Clearance between next } \\
\text { Building }\end{array}$} & North: & \multicolumn{2}{|l|}{$\mathrm{ft}$} \\
\hline & South: & \multicolumn{2}{|l|}{$\mathrm{ft}$} \\
\hline & \multicolumn{3}{|l|}{ East: $\mathrm{ft}$} \\
\hline & \multicolumn{3}{|l|}{ West:ft } \\
\hline 2.3 Width of Front Road & & & \\
\hline
\end{tabular}

3. Floor Area of the house

Sq. Ft

4. No. of Occupants:

5. Occupant Density: (Floor Area / Occupants)

Sq. Ft/Person

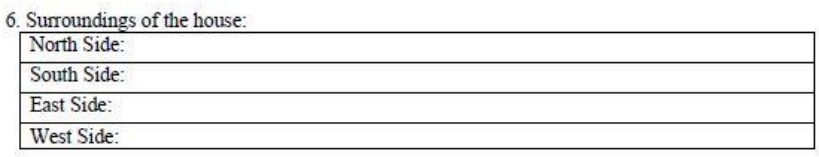

7. Ventilation System:

7.1. Natural Ventilator:

Single Opening

Two Opening in same wall

Two Opening in adjacent wal

Stack Ventilator

\begin{tabular}{|l|l|}
\hline$\square$ Yes & $\square$ No \\
\hline$\square$ Yes & $\square$ No \\
\hline$\square$ Yes & $\square$ No \\
\hline$\square$ Yes & $\square$ No \\
\hline
\end{tabular}

7.2. Mechanical ventilator:

\begin{tabular}{|l|l|l|}
\hline \multirow{2}{*}{ Ceiling fan } & $\square$ Yes & $\square$ No \\
\cline { 2 - 3 } & $\square$ Adequate & $\square$ Inadequate \\
\hline \multirow{3}{*}{ Exhaust fan } & $\square$ Yes & $\square$ No \\
\cline { 2 - 3 } & $\square$ Adequate & $\square$ Inadequate \\
\hline \multirow{2}{*}{ Bath Fans } & $\square$ Yes & $\square$ No \\
\cline { 2 - 3 } & $\square$ Adequate & $\square$ Inadequate \\
\hline
\end{tabular}

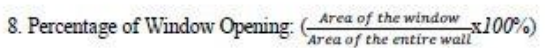

\section{Standard Value: $40 \%$}

\section{Dust Problems in the House:}

9. Dust Problems in the House:
\begin{tabular}{|l|l|l|l|}
\hline$\square$ High & $\square$ Medium & $\square$ Low & $\square$ Very Low \\
\hline
\end{tabular}

10. Chemical Contaminants from indoor sources:

\begin{tabular}{|l|l|l|}
\hline Air freshener, Aerosol & $\square$ Yes & $\square$ No \\
\hline Tobacco & $\square$ Yes & $\square$ No \\
\hline
\end{tabular}

11. Chemical Contaminants from outdoor sources:

11. Chemical Contaminants from outdoor sources:
\begin{tabular}{|l|l|l|}
\hline General Vehicle Exhaust & $\square$ Yes & $\square$ No \\
\hline Odors from Drmpsters & $\square$ Yes & $\square$ No \\
\hline Exhaust from Neighboring Buildings & $\square$ Yes & $\square$ No \\
\hline Exhaust From Generators & $\square$ Yes & $\square$ No \\
\hline
\end{tabular}

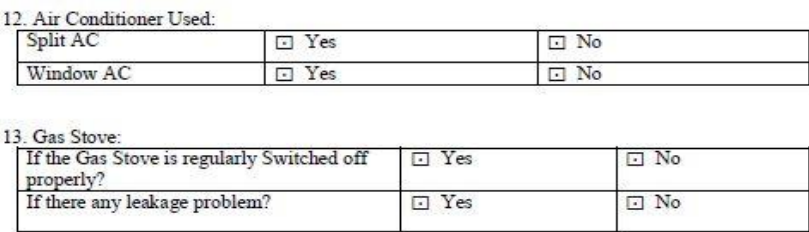

14. Temperature measured:
${ }^{\circ} \mathrm{C}$

15. Relative Humidity:

16. How long do the lights kept on

Day time:Hr

Night time: Hr

17. Safety Issues:
Fire Extinguishe

\begin{tabular}{|l|l|l} 
& $\square$ Yes & $\square$ No \\
\hline Emergency Fire Exits & $\square$ Yes & $\square$ No \\
\hline
\end{tabular}

18. Waste Collection System:

18. Waste Collection System:
\begin{tabular}{|l|l|l|}
\hline Garbage Chute & $\square$ Yes & $\square$ No \\
\hline House to house & $\square$ Yes & $\square$ No \\
\hline Community bins & $\square$ Yes & $\square$ No \\
\hline Curbside Pick up & $\square$ Yes & $\square$ No \\
\hline Self-delivered & $\square$ Yes & $\square$ No \\
\hline Thrown in the road, open spaces & $\square$ Yes & $\square$ No \\
\hline
\end{tabular}

\begin{tabular}{|l|l}
\hline Thrown in the road, open spaces & $\square$ Yes \\
\hline
\end{tabular}

19. Noise Pollution

$\square$ Low

$\square$ Medium

$\square$ Severe

20.Water Availability:

Sufficiently Available

\begin{tabular}{|l|l|l|}
\hline Extra Pump for Sucking Water & $\square$ Yes & $\square$ No \\
\hline
\end{tabular}

21. Quality of the Available Water:

\begin{tabular}{|l|l|l|l|l|}
\hline Odor & $\square$ Yes \\
\hline
\end{tabular}

\begin{tabular}{l|l}
\hline Bad taste & Yes \\
\hline
\end{tabular}

\begin{tabular}{|l|l|}
\hline Turbid & $\square$ Yes \\
\hline Sabity
\end{tabular}

\begin{tabular}{|l|l|l|}
\hline Salinity & $\square$ Yes & $\square$ No \\
\hline Potable & $\square$ Yes & No \\
\hline
\end{tabular}

22. Plumbing Problems:

\begin{tabular}{|l|l|l|}
\hline Dripping from the faucets & $\square$ Yes & $\square$ No \\
\hline $\begin{array}{l}\text { Presence of a leak along the baseboard of walls } \\
\text { near the location of plumbing fixture }\end{array}$ & $\square$ Yes & $\square$ No \\
\hline Slow drainage problem & $\square$ Yes & $\square$ No \\
\hline Surface drain presence & $\square$ Yes & $\square$ No \\
\hline Low water pressure & $\square$ Yes & $\square$ No \\
\hline Septic tank system & $\square$ Yes & $\square$ No \\
\hline Presence of Soak well & $\square$ Yes & $\square$ No \\
\hline
\end{tabular}

23. Toilet Environment:

\begin{tabular}{|c|c|c|}
\hline No. of the bathroom & & \\
\hline Odor & $\square$ Yes & $\square$ No \\
\hline Ventilator & $\square$ Natural & $\square$ Mechanical \\
\hline Vent pipe & $\square$ Yes & $\square$ No \\
\hline Commode & $\square$ European & Squatting \\
\hline
\end{tabular}

24. Dampness in the Building:

\begin{tabular}{|l|l|l|}
\hline Rising damp in wall & $\square$ Yes & $\square$ No \\
\hline Penetrating damp & $\square$ Yes & $\square$ No \\
\hline Damp in the roof & $\square$ Yes & $\square$ No \\
\hline Damp due to Drain pipe & $\square$ Yes & $\square$ No \\
\hline
\end{tabular}

